Szylińska Aleksandra, Mińko Alicja, Hilicka Zuzanna, Turzyński Dominik, Udzik Jakub, Sulikowski Piotr, Grabińska Izabela, Rotter Iwona. Evaluation of effort tolerance in diabetic and non-diabetic patients undergoing cardiac rehabilitation after cardiac surgery. Journal of Education, Health and Sport. 2020;10(8):383-392. eISSN 2391-8306. DOI http://dx.doi.org/10.12775/JEHS.2020.10.08.046 https://apcz.umk.pl/czasopisma/index.php/JEHS/article/view/JEHS.2020.10.08.046 https://zenodo.org/record/4006033

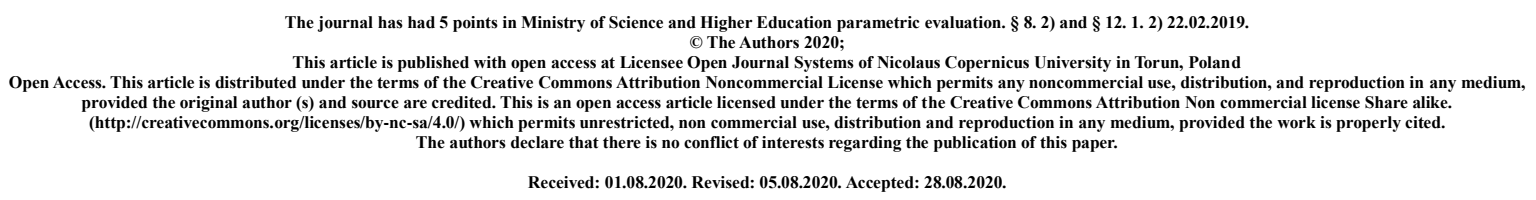

Received: 01.08.2020. Revised: 05.08.2020. Accepted: 28.08.2020.

\title{
Evaluation of effort tolerance in diabetic and non-diabetic patients undergoing cardiac rehabilitation after cardiac surgery
}

\author{
Aleksandra Szylińska ${ }^{1}$, Alicja Mińko², Zuzanna Hilicka², Dominik Turzyński \\ Jakub Udzik ${ }^{3}$, Piotr Sulikowski ${ }^{4}$, Izabela Grabińska ${ }^{5}$, Iwona Rotter ${ }^{1}$
}

1. Department of Medical Rehabilitation and Clinical Physiotherapy, Pomeranian Medical University in Szczecin, ul. Żołnierska 54, 70-204 Szczecin, Poland

2. Students' Science Club of Department of Medical Rehabilitation and Clinical Physiotherapy, Pomeranian Medical University in Szczecin, ul. Żołnierska 54, 70-204 Szczecin, Poland

3. Students' Science Club of The Department of Cardiac Surgery, Pomeranian Medical University in Szczecin, al. Powstańców Wielkopolskich 72, 70-111 Szczecin, Poland

4. Faculty of Computer Science and Information Technology, West Pomeranian University of Technology, ul. Żołnierska 49, 71-210 Szczecin, Poland

5. Cardiac Rehabilitation Department, University Hospital of the Pomeranian Medical University in Szczecin (SPSK 2 PUM), al. Powstańców Wielkopolskich 72, 70-111 Szczecin, Poland

Corresponding author: Dominik Turzyński², e-mail: turzynski.d@edu.pum.edu.pl 


\begin{abstract}
Introduction: Complex cardiac rehabilitation is a basic procedure of therapeutic treatment for patients after cardiac surgeries. The course of operations depends on many factors. The aim of this article is to investigate connections between type 2 diabetes and results of 6minute walk test among patients after cardiac surgery.
\end{abstract}

Materials and methods: This research was conducted among 111 patients who had cardiac surgery. Those patients were qualified to stay at a stationary cardiac rehabilitation facility. They were divided into two groups: patients with and without diabetes. In the analysis, patients' medical data and 6-minute walk test results before and after complex rehabilitation were taken into consideration.

Results: On the basis of our analysis it was found that patients who have diabetes achieve worse results of 6 -minute walk test before $(O R=0.995 ; \mathrm{p}=0.005)$ and after $(\mathrm{OR}=0.994$, $\mathrm{p}=0.006$ ) complex cardiac rehabilitation in comparison with patients without diabetes.

Conclusions: Type 2 diabetes has impact on physical effort tolerance among patients after cardiac surgery. Despite improvement of 6-minute walk test results thanks to complex cardiac rehabilitation, patients with type 2 diabetes walked shorter distance than patients without diabetes.

Keywords: cardiac rehabilitation, cardiology, 6-minute walk test, type 2 diabetes

\title{
Introduction
}

Complex cardiac rehabilitation is a basic procedure of therapeutic treatment for patients after cardiac surgeries [1]. Its actions are mostly aiming at reduction of the risk of secondary coronary incidents, as well as improvement of efficiency, functional abilities and life quality $[2,3]$. Its course depends on many factors. One of them is co-occurrence of diabetes among cardiological patients, which is an increasing health problem [1].

According to epidemiological data, there are 170 million people around the world who have diabetes [4]. It is believed that diabetes is strongly related to coronary disease, which is the most common illness within circulatory system. When someone has diabetes, it is 2-4 times more probable to have a coronary disease and that has a significant impact on results of cardiological patients' rehabilitation [5,6,7]. It is connected with faster progression of atherosclerosis of coronary arteries, higher probability of thrombotic incidents or endothelial dysfunction occurring in this group [5]. Moreover, adverse effects of hyperglycemia contribute to damage of function and structure of cardiomyocytes. It is connected with increase of free fatty acids and inhibition of uptake and release of glucose, which in consequence leads to decreased ability to transport oxygen to cardiomyocytes. Additionally, increased concentration of free radicals damage contractile proteins of the heart and increased collagen glycation level lead to myocardial stiffness, which can be the cause of ventricular dysfunction during diastole [6]. Patients with diagnosed diabetes who are qualified for cardiac surgery are burdened with higher perioperative risk and more rigorous therapeutic aims than patients without diabetes $[1,8]$.

The main aim of this paper is to determine correlation between type 2 diabetes and 6-minute walk test results within patients after cardiac surgery incidents. 


\section{Material and methods}

The study was conducted in SPSK2 Clinic of Cardiac Surgery of the Pomeranian Medical University in Szczecin. Patients who took part in the study had cardiac surgery with sternotomy. After surgery patients were qualified to stay at a stationary cardiac rehabilitation facility between March and December 2019. There were 111 patients who participated in the study $-87(78.4 \%)$ men and $24(21.6 \%)$ women. Their average age was 66.9 years old ( \pm 11.2). We assumed the following exclusion criteria: no complete data available in medical records, non-participation in stationary cardiac rehabilitation after surgery or contraindications to participation in cardiac rehabilitation.

Using medical reports, data including diagnosis, comorbidities, ejection fraction, C-reactive protein (CRP), creatinine (Cr), glomerular filtration rate (GFR), and glycated hemoglobin (HbA1c) were obtained. Moreover, in the study we used 6-minute walk test results which measure physical capacity. This test was conducted 2 times, when a patient was admitted to the rehabilitation department and just before he was going home. During the test measurements of blood pressure and pulse were also recorded.

\section{6-minute walk test}

A patient before 6-minute walk test is sitting in one place for 10 minutes in order to rest. When the patient is ready, the physiotherapist says "go" and the test is started. The patient then walks for 6 minutes in his own pace - not too slow, not too fast down the 30 metres long rehabilitation department hall, where start, turning spot and stop lines were earlier marked. Straight before and after the test, the physiotherapist measures the patient's blood pressure and pulse. When the patient feels chest pain, shortness of breath, has pale face or balance disorders, the test is interrupted and it is repeated when the clinical condition is stabilized.

\section{Cardiac rehabilitation}

The duration of complex rehabilitation in stationary mode was 3 weeks in cycles from Monday to Saturday. The forms of restoring physical strength were daily patting, breathing exercises performed 10 to 15 times per hour during the day using Triflo excerciser, antiedema exercises of lower limbs every hour, walking down the corridor, training on cycloergometers as well as group exercises, which included equipment-free exercises, resistance and relaxing exercises and exercises for lower limbs on a rotor 6 times a day for 10-20 minutes.

\section{Ethics and approvals}

The study was conducted in accordance with the conditions of the Declaration of Helsinki. It received an approval from the Bioethical Committee of the Pomeranian Medical University (decision no. KB- 0012/16/01/19).

\section{Analysis}

Statistical analysis was performed using Statistica 13 software (StatSoft, Inc., Tulsa, OK, USA). The normality of quantitative data distribution was assessed using the Shapiro-Wilk test. Quantitative data were presented as mean, SD and median and evaluated using the Mann-Whitney U test. 
Categorical variables were presented as proportions and analyzed using the Chi-squared test or Chi-square test with Yates correction. Univariate and multivariate logistic regression analysis was performed and presented as odds ratio with 95\% confidence interval. Multivariate analysis was adjusted by age, sex, BMI and smoking. The p-value $\leq 0.05$ was regarded as statistically significant. Data were also explored using data mining techniques, including rough sets.

\section{Results}

Characteristics of patients depending on the incidence of diabetes are demonstrated in Table 1. Mean value of glycated hemoglobin [\%] in patients without diabetes was $5.86( \pm 0.49)$ while in those with diabetes it was nearly $20 \%$ higher and reached the value of $7.03( \pm 1.25)$. Difference between the groups was statistically relevant $(\mathrm{p}<0.001)$.

Moreover, patients with diabetes had mean plasma CRP concentration level of $6.16 \mathrm{mg} / \mathrm{L}( \pm$ 11.45), while in patients without diabetes that value was lower and reached $4.60 \mathrm{mg} / \mathrm{L}( \pm$ 8.39), with statistically relevant difference between the groups $(\mathrm{p}=0.038)$. Patients with diabetes had lower mean preoperative left ventricular ejection fraction [\%] comparing to patients without diabetes $(40.00 \pm 9.20$ vs $50.00 \pm 10.63$ respectively, $\mathrm{p}=0.007)$, but demonstrated greater improvement in ejection fraction after the surgery (45.00 $\pm 8.15 \mathrm{vs}$. $50.00 \pm 10.63$ in control group).

Table 1. Demographic data, medical history and selected parameters depending on the incidence of diabetes.

\begin{tabular}{|c|c|c|c|c|}
\hline \multicolumn{2}{|c|}{ Demographic data } & $\begin{array}{l}\text { Without diabetes } \\
\qquad(n=77)\end{array}$ & $\begin{array}{l}\text { With diabetes } \\
\qquad(n=34)\end{array}$ & $\mathbf{p}$ \\
\hline \multicolumn{5}{|c|}{ Demographic data } \\
\hline \multicolumn{2}{|c|}{$\begin{array}{l}\text { Age [years] (mean } \pm \text { SD; } \\
\mathrm{Me})\end{array}$} & $66.13 \pm 11.88 ; 67.00$ & $68.74 \pm 9.21 ; 68.00$ & 0.528 \\
\hline \multirow{2}{*}{$\begin{array}{l}\operatorname{Sex}(\mathrm{n}, \\
\%)\end{array}$} & male & $61(79.22 \%)$ & $26(76.47 \%)$ & \multirow{2}{*}{0.941} \\
\hline & female & $16(20.78 \%)$ & $8(23.53 \%)$ & \\
\hline \multirow{3}{*}{$\begin{array}{l}\mathrm{BMI} \\
\text { range } \\
(\mathrm{n}, \%)\end{array}$} & normal & $15(22.39 \%)$ & $7(21.88 \%)$ & \multirow{3}{*}{0.104} \\
\hline & overweight & $36(53.73 \%)$ & $11(34.38 \%)$ & \\
\hline & obesity & $16(23.88 \%)$ & $14(43.75 \%)$ & \\
\hline \multicolumn{2}{|c|}{ BMI (mean $\pm S D ; M e)$} & $27.90 \pm 4.43 ; 27.78$ & $28.97 \pm 4.43 ; 29.15$ & 0.197 \\
\hline \multicolumn{2}{|c|}{ Smoking (n, \%) } & $11(30.56 \%)$ & $3(15.79 \%)$ & 0.384 \\
\hline
\end{tabular}




\begin{tabular}{|c|c|c|c|}
\hline \multicolumn{4}{|l|}{ Medical history } \\
\hline Heart failure $(\mathrm{n}, \%)$ & $62(80.52)$ & $32(94.12 \%)$ & 0.122 \\
\hline $\begin{array}{l}\text { Arterial hypertension (n, } \\
\% \text { ) }\end{array}$ & $57(74.03 \%)$ & $29(85.29 \%)$ & 0.288 \\
\hline Renal failure (n, \%) & $14(18.18 \%)$ & $10(29.41 \%)$ & 0.283 \\
\hline Arrhythmias (n, \%) & $15(19.48 \%$ & $8(23.53 \%)$ & 0.817 \\
\hline $\operatorname{COPD}(\mathrm{n}, \%)$ & $5(6.49 \%)$ & $2(5.88 \%)$ & 0.763 \\
\hline \multicolumn{4}{|l|}{ Preoperative parameters } \\
\hline $\mathrm{EF}[\%]($ mean $\pm \mathrm{SD} ; \mathrm{Me})$ & $46.82 \pm 10.63 ; 50.00$ & $40.83 \pm 9.20 ; 40.00$ & 0.007 \\
\hline $\begin{array}{l}\text { Glycated hemoglobin [\%] } \\
(\text { mean } \pm \text { SD; Me) }\end{array}$ & $5.86 \pm 0.49 ; 5.80$ & $7.03 \pm 1.25 ; 6.60$ & $<0.001$ \\
\hline $\begin{array}{l}\mathrm{CRP}[\mathrm{mg} / \mathrm{L}](\text { mean } \pm \mathrm{SD} \\
\mathrm{Me})\end{array}$ & $4.60 \pm 8.39 ; 1.51$ & $6.16 \pm 11.45 ; 2.92$ & $\mathbf{0 . 0 3 8}$ \\
\hline \multicolumn{4}{|l|}{ Postoperative parameters } \\
\hline $\mathrm{EF}[\%]($ mean $\pm \mathrm{SD} ; \mathrm{Me})$ & $47.05 \pm 10.86 ; 50.00$ & $41.76 \pm 8.15 ; 45.00$ & 0.004 \\
\hline $\begin{array}{l}\mathrm{CRP}[\mathrm{mg} / \mathrm{L}](\text { mean } \pm \mathrm{SD} \\
\mathrm{Me})\end{array}$ & $\begin{array}{l}248.33 \pm 95.13 \\
264.90\end{array}$ & $\begin{array}{l}255.26 \pm 105.27 \\
249.24\end{array}$ & 0.995 \\
\hline $\begin{array}{l}\mathrm{GFR} \\
{[\mathrm{ml} / \mathrm{min} / \mathrm{m} 2](\text { mean } \pm \mathrm{SD} ;} \\
\mathrm{Me})\end{array}$ & $75.00 \pm 19.42 ; 79.50$ & $71.64 \pm 21.94 ; 74.00$ & 0.522 \\
\hline $\begin{array}{l}\text { Creatinine }[\mathrm{mg} / \mathrm{dl}] \\
(\text { mean } \pm \mathrm{SD} ; \mathrm{Me})\end{array}$ & $1.04 \pm 0.31 ; 0.98$ & $1.10 \pm 0.56 ; 0.97$ & 0.744 \\
\hline
\end{tabular}

Legend: $\mathrm{n}$ - number of patients, $\mathrm{p}$ - statistical significance, $\mathrm{SD}$ - standard deviation, Me - median, BMI - body mass index $\left(\mathrm{kg} / \mathrm{m}^{2}\right)$, COPD - chronic obstructive pulmonary disease, CABG - coronary artery bypass grafting,

CRP - C-reactive Protein, GFR - glomerular filtration rate.

In the study it was concluded that patients suffering from diabetes obtained significantly lower 6-minute walk test results both before (mean distance $238.00 \pm 126.10 \mathrm{~m}, \mathrm{p}=0.005$ ) and after complex cardiac rehabilitation (mean distance $386.21 \pm 120.15 \mathrm{~m}, \mathrm{p}=0.006$ ), comparing to control group (mean distance $307.70 \pm 107.58 \mathrm{~m}, \mathrm{p}=0.005$ and $446.32 \pm 87.33$ $\mathrm{m}$, respectively before and after rehabilitation). Detailed results are demonstrated in Table 2. Mean diastolic blood pressure at discharge from the rehabilitation department was $12 \%$ lower in patients with diabetes comparing to control group $(\mathrm{p}=0.028)$. 
Table 2. 6-minute walk test results in patients with and without diabetes.

\begin{tabular}{|c|c|c|c|c|}
\hline & $\begin{array}{l}\text { Without diabetes } \\
\qquad(n=77)\end{array}$ & With diabetes $(n=34)$ & $\mathbf{p}$ \\
\hline & & mean $\pm \mathrm{SD} ; \mathrm{Me}$ & mean $\pm \mathrm{SD} ; \mathrm{Me}$ & \\
\hline \multicolumn{2}{|c|}{ First 6-MWT distance [m] } & $\begin{array}{c}307.70 \pm 107.58 \\
330.00\end{array}$ & $\begin{array}{c}238.00 \pm 126.10 \\
227.50\end{array}$ & 0.005 \\
\hline \multirow{2}{*}{$\begin{array}{l}\text { Systolic pressure } \\
{[\mathrm{mm} \mathrm{Hg}]}\end{array}$} & before & $125.18 \pm 13.81 ; 127.00$ & $128.41 \pm 13.38 ; 131.00$ & 0.235 \\
\hline & after & $136.61 \pm 17.20 ; 139.00$ & $135.32 \pm 32.23 ; 136.50$ & 0.849 \\
\hline \multicolumn{2}{|c|}{$\begin{array}{l}\text { Difference in systolic pressure } \\
{[\mathrm{mm} \mathrm{Hg}]}\end{array}$} & $11.68 \pm 12.54 ; 10.50$ & $13.38 \pm 20.07 ; 11.50$ & 0.651 \\
\hline \multirow{2}{*}{$\begin{array}{l}\text { Diastolic pressure } \\
{[\mathrm{mm} \mathrm{Hg}]}\end{array}$} & before & $75.26 \pm 9.51 ; 75.00$ & $71.74 \pm 11.91 ; 70.50$ & 0.098 \\
\hline & after & $78.00 \pm 10.72 ; 77.50$ & $69.35 \pm 22.01 ; 69.50$ & 0.028 \\
\hline \multicolumn{2}{|c|}{$\begin{array}{l}\text { Difference in diastolic } \\
\text { pressure }[\mathrm{mm} \mathrm{Hg}]\end{array}$} & $3.30 \pm 7.64 ; 3.00$ & $2.15 \pm 8.63 ; 2.00$ & 0.253 \\
\hline \multirow{2}{*}{ Heart rate } & before & $78.95 \pm 10.46 ; 78.00$ & $78.65 \pm 11.51 ; 83.00$ & 0.836 \\
\hline & after & $86.70 \pm 12.34 ; 88.00$ & $87.71 \pm 14.26 ; 89.00$ & 0.893 \\
\hline \multicolumn{2}{|c|}{ Difference in heart rate } & $7.61 \pm 8.46 ; 6.50$ & $9.44 \pm 12.88 ; 6.00$ & 0.954 \\
\hline \multicolumn{2}{|c|}{ Last 6-MWT distance [m] } & $446.32 \pm 87.33 ; 448.00$ & $\begin{array}{c}386.21 \pm 120.15 \\
379.50\end{array}$ & 0.006 \\
\hline \multirow{2}{*}{$\begin{array}{l}\text { Systolic pressure } \\
{[\mathrm{mm} \mathrm{Hg}]}\end{array}$} & before & $122.58 \pm 14.17 ; 123.00$ & $124.03 \pm 13.34 ; 124.00$ & 0.596 \\
\hline & after & $139.66 \pm 18.16 ; 141.50$ & $142.35 \pm 20.54 ; 140.00$ & 0.691 \\
\hline \multicolumn{2}{|c|}{$\begin{array}{l}\text { Difference in systolic pressure } \\
{[\mathrm{mm} \mathrm{Hg}]}\end{array}$} & $17.74 \pm 15.17 ; 17.50$ & $18.03 \pm 17.29 ; 20.00$ & 0.859 \\
\hline \multirow{2}{*}{$\begin{array}{l}\text { Diastolic pressure } \\
{[\mathrm{mm} \mathrm{Hg}]}\end{array}$} & before & $69.48 \pm 9.43 ; 69.50$ & $69.74 \pm 11.89 ; 67.00$ & 0.977 \\
\hline & after & $73.88 \pm 12.02 ; 74.00$ & $74.06 \pm 12.92 ; 72.00$ & 0.990 \\
\hline
\end{tabular}




\begin{tabular}{|l|c|c|c|c|}
\hline \multicolumn{2}{|l|}{$\begin{array}{l}\text { Difference in diastolic } \\
\text { pressure [mm Hg] }\end{array}$} & $4.40 \pm 9.60 ; 4.00$ & $4.32 \pm 12.75 ; 3.50$ & 0.997 \\
\hline \multirow{2}{*}{ Heart rate } & before & $70.32 \pm 10.04 ; 67.50$ & $73.21 \pm 11.93 ; 71.00$ & 0.300 \\
\cline { 2 - 5 } & after & $79.86 \pm 13.68 ; 76.50$ & $80.15 \pm 12.86 ; 80.00$ & 0.856 \\
\hline Difference in heart rate & $9.54 \pm 7.59 ; 9.00$ & $6.94 \pm 10.31 ; 9.00$ & 0.593 \\
\hline $\begin{array}{l}\text { Difference in 6-MWT } \\
\text { distance [m] }\end{array}$ & $\mathbf{1 3 5 . 2 0 \pm 8 3 . 6 6 ; 1 1 0 . 0 0}$ & $\mathbf{1 4 4 . 4 1 \pm 7 4 . 4 8 ; 1 4 7 . 0 0}$ & $\mathbf{0 . 2 6 6}$ \\
\hline
\end{tabular}

Legend: $\mathrm{n}$ - number of patients, $\mathrm{p}$ - statistical significance, SD - standard deviation, Me - median, 6-MWT - 6minute walk test.

Evaluation of relationships between 6-minute walk test results and incidence of diabetes was conducted. In patients with diabetes both the initial $(\mathrm{OR}=0.995 ; \mathrm{p}=0.005)$ and final $(\mathrm{OR}=0.994 ; \mathrm{p}=0.006)$ 6-minute walk test results were significantly lower. The regression analysis adjusted for age, sex, BMI and smoking confirmed the decrease in march distance in patients with diabetes, both in the initial $(\mathrm{OR}=0.994 ; \mathrm{p}=0.049)$ and final measurements $(\mathrm{OR}=0.992 ; \mathrm{p}=0.027)$, as illustrated in Table 3 .

Table 3. Multifactorial regression analysis in patients with and without diabetes.

\begin{tabular}{|l|c|c|c|c|c|c|c|c|}
\hline \multirow{2}{*}{} & \multicolumn{7}{|c|}{ Without diabetes (n=77) } & \multicolumn{3}{c|}{ With diabetes (n=34) } \\
\cline { 2 - 8 } & $\begin{array}{c}\mathrm{p}- \\
\text { value }\end{array}$ & OR & $\begin{array}{c}\text { CI - } \\
95 \%\end{array}$ & $\mathrm{Cl}+95 \%$ & $\begin{array}{c}\mathrm{p}- \\
\text { value }\end{array}$ & OR & Cl -95\% \\
\hline Not Adjusted & $\mathbf{0 . 0 0 5}$ & 1.005 & 1.002 & 1.009 & $\mathbf{0 . 0 0 5}$ & 0.995 & 0.991 \\
\hline $\begin{array}{l}\text { Initial 6-MWT } \\
\text { distance [m] }\end{array}$ & $\mathbf{0 . 0 0 6}$ & 1.006 & 1.002 & 1.010 & $\mathbf{0 . 0 0 6}$ & 0.994 & 0.990 \\
\hline $\begin{array}{l}\text { Final 6-MWT } \\
\text { distance [m] }\end{array}$ & $\mathbf{0 . 0 4 9}$ & 1.006 & 1.000 & 1.012 & $\mathbf{0 . 0 4 9}$ & 0.994 & 0.989 \\
\hline Adjusted & $\mathbf{0 . 0 2 7}$ & 1.008 & 1.001 & 1.016 & $\mathbf{0 . 0 2 7}$ & 0.992 & 0.984 \\
\hline $\begin{array}{l}\text { Initial 6-MWT } \\
\text { distance [m] }\end{array}$ & $\begin{array}{l}\text { Final 6-MWT } \\
\text { distance [m] }\end{array}$ & & & & & & & \\
\hline
\end{tabular}

Legend: $\mathrm{p}$ - statistical significance, OR - odds ratio, CI- confidence interval, 6-MWT - 6-minute walk test. 


\section{Discussion}

The relationship between the incidence of type 2 diabetes and 6-minute walk test results in patients after cardiac surgery procedures was examined in this study using statistics and other data mining techniques. In order to assess patients' physical performance, 6-minute walk test was used, combined with heart rate and arterial blood pressure measurements. It is a safe test that does not require specialist equipment and demonstrates each patient's functional state. This test also enables to measure the progress in physiotherapy process in subsequent treatment stages [9].

According to our study, it was concluded that diabetes affects physical effort tolerance in patients after cardiac surgery procedures. Patients suffering from type 2 diabetes obtained worse 6-minute walk test results both before and after the rehabilitation, comparing to patients without any carbohydrates metabolism disorders. This proves not only the unquestionably beneficial influence of rehabilitation in both groups, but also shows impaired physical performance in patients with concomitant type 2 diabetes.

Laddu et al. published an analysis of patients with diabetes who underwent cardiac rehabilitation, however with a difference in the form of complex rehabilitation and evaluated factors. Those patients were subjected to 12-week rehabilitation, which consisted of doing training for one hour twice a week with specialist supervision, doing individual exercise sessions, personalised health education and constant access to an interdisciplinary rehabilitation team. The study reported common occurrence of maximal metabolic equivalent (METs) and especially insulin resistance in patients with both ischemic heart disease and diabetes as well as patients without diabetes, enrolled in a complex rehabilitation program. After completing the program, the incidence of METs decreased and variuos cardiacmetabolic disorders improved. The improvement, however, was generally insubstantial among patients with diabetes, comparing to patients without diabetes [2].

Eser et al. concluded that immediate improvement in peak $\mathrm{VO}_{2}$ after rehabilitation was similar in patients with and without diabetes. Nonetheless, in 12-months observation the maintenance of this improvement was worse in patients with diabetes, which was probably due to progress of the disease. These results were based on the examination of 1633 patients who underwent cardiac surgery procedures in eight European facilities and were subjected to cardiac rehabilitation [10].

Völler et al. concluded that complex cardiac rehabilitation program leads to optimization of cardiovascular risk factors both in diabetic and healthy patients [11]. This conclusion derived from the analysis of parameters of patients who suffered from acute cardiac incident and were subsequently subjected to cardiac rehabilitation which lasted about 23 days and consisted of physical exercise and dietetic counselling.

The influence of cardiac rehabilitation on physical and hemodynamic performance of patients with concomitant type 2 diabetes was assessed also by Głowacka et al. The difference in their approach was consisting in including in the study only patients who had had myocardial infarction. 47 patients qualified for 3 weeks of stationary rehabilitation were examined. Type 2 diabetes was found in 21 of them, and those patients were included in the study group. The rest of 26 patients were included in the control group. All patients were subjected to total of 15 training sessions five times a week, which consisted of: ergometer training, general rehabilitation gymnastics, psychoeducation and music therapy. 
Basing on the analysis, it was observed that training time improved in both groups. Moderately better results were achieved by patients with no carbohydrates metabolism disorders, whose test time increased by $16 \%$, while in patients with diabetes it decreased by $3 \%$. Resting values of heart rate and arterial blood pressure were comparable in both groups. Beneficial results of cardiac rehabilitation were observed in both groups, but concomitant type 2 diabetes was related to worse physical performance and, thus, to worse rehabilitation outcomes [6].

Physical exercise has relevant impact on glucose level in serum, which is why it is recommended to people with impaired carbohydrate metabolism. Aerobic exercise performed at least 3-4 times a week for 20-60 minutes and involving large muscle groups of upper and lower limbs enable patients to maintain normal glucose level. Moreover, doing resistance exercise 2-3 times a week also has a positive effect on patients' condition.

According to Seguro C. et al. only 40 minutes of resistance exercise a week may contribute to improvement in general health condition and quality of life in patients with type 2 diabetes and arterial hypertension. They supported that claim with a case study in which they proved decrease in blood glucose level, systolic and diastolic blood pressure and resting heart rate in patients with coronary artery disease, type 2 diabetes and arterial hypertension, subjected to 15 weeks of resistance exercise [6,12].

The influence of physical activity in cardiac patients was also investigated by Denegri et al., who proved that cardiac rehabilitation program has a positive impact on glycemic control [13].

\section{Conclusions}

According to our analyses, type 2 diabetes influences physical effort tolerance in patients after cardiac surgery procedures. Despite the improvement of 6-minute walk test results due to complex cardiac rehabilitation, patients with type 2 diabetes walked significantly shorter distances in that test comparing to patients without diabetes. 


\section{Bibliography}

1. Zielińska D., Bellwon J., Biernat A., Toruński A., Mierzejewski L., Bakuła S.: Bezpieczeństwo i skuteczność rehabilitacji kardiologicznej u chorych na cukrzyce po leczeniu operacyjnym choroby wieńcowej. Kardiol Pol 2009; 67: 941-945.

2. Laddu D.R., Ozemek C., Hauer T.L., Rouleau C.R., Campbell T.S., Wilton S.B. i wsp.: Cardiometabolic responses to cardiac rehabilitation in people with and without diabetes. Int J Cardiol 2020 Feb 15;301:156-162.

3. Kachur S., Chongthammakun V., Lavie C. J., De Schutter A., Arena R., Milani R. V. i wsp.: Impact of cardiac rehabilitation and exercise training programs in coronary heart disease. Progress in Cardiovascular Diseases 2017; 60(1); 103-114.

4. Górska-Ciebiada M., Ciebiada M., Barylski M., Loba J.: Cukrzyca u osób w wieku podeszlym $w$ świetle nowych wytycznych Polskiego Towarzystwa Diabetologicznego. Geriatria 2009; 3: 228-233.

5. Ścibisz A., Wilczyńska J., Michalak M., Pietrasik A.: Chory z cukrzyca i choroba wieńcowa - dyskusyjny pacjent w pracowni kardiologii inwazyjnej. Kardiol Dypl 2010; 9 (7): 77-83.

6. Głowacka P., Mizia-Stec K., Gąsior Z.: Cukrzyca typu 2 a rehabilitacja pacjentów po zawale mięśnia sercowego. Fizjoter Pol 2010; 4(4); Vol. 10, 289-297.

7. Rejestr głównych typów operacji kardiochirurgicznych w 2015 r. w poszczególnych ośrodkach w Polsce (wg Krajowego Rejestru Operacji Kardiochirurgicznych KROK). Kardiochir Torakochirurgia Pol. 2016; 13(2): 185-188.

8. Pres D., Gąsior M., Poloński L.: Leczenie pacjentów z choroba wieńcowa i cukrzycą. Choroby Serca i Naczyń 2010; 7 (3); 112-117.

9. Dourado VZ.: Reference Equations for the 6-Minute Walk Test in Healthy Individuals. Arq Bras Cardiol Feb. 2011.

10. Eser P., Marcin T., Prescott E., Prins L.F., Kolkman E., Bruins W. i wsp.: Clinical outcomes after cardiac rehabilitation in elderly patients with and without diabetes mellitus: The EU-CaRE multicenter cohort study. Cardiovasc Diabetol 2020; 19;19(1):37.

11. Völler, H., Reibis, R., Pittrow, D., Jannowitz, C., Wegscheider, K., Karmann, B. i wsp.: Secondary prevention of diabetic patients with coronary artery disease in cardiac rehabilitation: risk factors, treatment and target level attainment. Current Medical Research and Opinion 2009; 25(4): 879-890.

12. Seguro C., Viana R., Lima G., Galvão L., Silva L., Jardim T. i wsp.: Improvements in health parameters of a diabetic and hypertensive patient with only 40 minutes of exercise per week: a case study. Disabil Rehabil. 2019; 23:1-7.

13. Denegri A., Rossi V.A., Vaghi F., Di Muro P., Regazzi M., Moccetti T., i wsp.: A patientcentered multidisciplinary cardiac rehabilitation program improves glycemic control and functional outcome in coronary artery disease after percutaneous and surgical revascularization. Cardiol J. 2020; 10. 